\title{
PELATIHAN GERAKAN PADA KONDISI ANAEROBIC DAPAT MENINGKATKAN WAKTU TEMPUH RENANG DADA 100 METER EKSTRAKURIKULER SISWA SMK NEGERI 2 KOTA KUPANG NUSA TENGGARA TIMUR
}

\author{
Maria Imaculata Date ${ }^{1}$, Luh Made Indah Sri Handari Adiputra ${ }^{2}$, I Putu Adiartha \\ Griadhi $^{3}$, Susy Purnawati ${ }^{4}$, I Made Muliarta ${ }^{5}$, I Made Krisna Dinata ${ }^{6}$. \\ ${ }^{1}$ Program Magister Fisiologi Keolahragaan Fakultas Kedokteran, Universitas Udayana \\ 2,3,4,5,6 Bagian Ilmu Faal, Fakultas Kedokteran, Universitas Udayana \\ e-mail : Merywahang29@gmail.com
}

\begin{abstract}
ABSTRAK
Gerakan renang pada kondisi anaerobic adalah kecepatan gerak dengan jarak yang singkat dalam waktu tempuh secepat-cepatnya yang sangat dibutuhkan untuk menentukan prestasi bagi performa para siswa. Hasil performa yang baik adalah pemberian beban berupa pengulangan, serta kecepatan gerak diukur dengan mengukur waktu tempuh jarak tertentu.Untuk membukitkan bahwa pelatihan gerakan pada kondisi anaerobic dapat meningkatkan waktu tempuh renang gaya dada 100 meter ekstrakurikuler siswa SMK Negeri 2 Kota Kupang Nusa Tenggara Timur. Penelitian ini menggunakan rancangan penelitian eksperimental Randomized pretest-posttest control group design melibatkan 26 orang siswa renang ekstrakulikuler, berumur 15-19 tahun, tinggi badan, berat badan, dengan indeks massa tubuh (IMT) yang normal dengan rerata $19,15 \pm 0,36 \mathrm{~kg} / \mathrm{m}^{2}$. Subjek penelitian dibagi menjadi dua kelompok yaitu Kelompok Perlakuan pelatihan renang pada kondisi anaerobic 8 x 25 meter pengulangan, 4 repetisi, 5 set, 3 x satu minggu selama 6 minggu, sedangkan Kelompok Kontrol pelatihan renang anaerobic 4 x 50 meter pengulangan, 3 repetisi, 5 set , 3 kali satu minggu selama 6 minggu. Penelitian menunjukan bahwa rerata waktu tempuh Kelompok Perlakuan sebelum pelatihan renang adalah 135,85 $\pm 4,85$ detik, sedangkan pada Kelompok Kontrol adalah $134,77 \pm 4,23$ detik, $t=0,604$ dan nilai $\mathrm{p}=0,552$. Setelah perlakuan rerata waktu tempuh Kelompok Perlakuan 114,23 $\pm 5,22$ detik, sedangkan pada Kelompok Kontrol adalah $126,08 \pm 5,07$ detik $\mathrm{t}=5,870$ dan nilai $\mathrm{p}<0,001$. Waktu tempuh siswa renang yang berbeda bermakna $(\mathrm{p}<0,05)$ antara ke dua kelompok, bahwa Pelatihan Gerakan Pada Kondisi Anaerobic dapat meninggkatkan waktu tempuh Renang Gaya Dada 100 Meter ekstrakurikuler Siswa SMK Negeri 2 Kota Kupang Nusa Tenggara Timur.
\end{abstract}

Kata kunci : Anaerobic, waktu tempuh, renang gaya dada 100 meter 
SWIMMING IN ANAEROBIC CONDITIONS CAN INCREASE THE

TRAVEL TIME OF BREASTSTROKE SWIMMING 100 METERS

EXTRACURRICULAR STUDENTS OF STATE VOCATIONAL HIGH SCHOOL 2 KUPANG CITY, EAST NUSA TENGGARA.

\begin{abstract}
Swimming with anaerobic conditions in a short distance in the fastest traveling time that is needed to determine the performance students. The results of good performance are the provision of meaningful load on repetition, and the speed of motion measured measuring the distance traveling time certain distance. Reveal that movement training in anaerobic conditions can increase the travel time of breaststroke swimming 100 meters extracurricular students of State Vocational High School 2 Kupang City, East Nusa Tenggara.This study used an eksperimental randomized pretest-posttest control group design involving 26 extracurricular swimming students, aged 15-19 years, height, and weight, with a normal body mass index (BMI) with an average of $19.15 \pm 0.36 \mathrm{~kg} / \mathrm{m}^{2}$. The research subjects were divided into two groups, namely the treatment group swimming training in anaerobic conditions $8 \times 25$ meters repetition, 4 repetitions, 5 sets, 3 times a week for 6 weeks, while the control group anaerobic swimming training 4 x 50 meters repetition, 3 reps, 5 sets, 3 times a week for 6 weeks. Showed that the average trevel time treatment group was swimming training $135.85 \pm 4.85$ seconds, while in the control group was $134.77 \pm 4.23$ seconds, $t=0.604$ and the value of $p=0.552$. While after treatment, average trevel time the treatment group was $114.23 \pm 5.22$ seconds, while in the control group it was swimming training $126.08 \pm 5.07$ seconds $t=-5.870$ and $p$ value $<0.001$. Travel times for swimming students were significantly different $(\mathrm{p}<0.05)$ between the two groups, movement Training in Anaerobic Conditions can increase travel time for 100-Meter breaststroke swimming style extracurricular Students of State Vocational High School 2 Kupang City, East Nusa Tenggara.
\end{abstract}

Keywords: Anaerobic, traveling time, 100 meter breaststroke pool.

\section{PENDAHULUAN}

Olahraga renang merupakan olahraga di Indonesia yang sangat populer bagi masyarakat umumnya dan lingkungan sekitar berada mulai dari jaman nenek moyang dari sekolah tingkat terendah sampai ke perguruan tinggi. Renang merupakan cabang olahraga air yang sangat menyenangkan dan memberi banyak manfaat bagi seluruh tubuh, antara lain membuat paru-paru sehat, sendi lebih lentur terutama di bagian leher, bahu, dan pinggul. Olahraga renang dengan tujuan untuk rekreasi, rehabilitasi, dan prestasi. Renang merupakan suatu cara yang dilakukan orang atau binatang untuk menggerakkan tubuhnya di air ${ }^{1}$. Pelatihan fisik sangat dibutuhkan pada olahraga renang untuk mencapai atau mampu memperoleh waktu tempuh yang maksimal, sebab itu memerlukan suatu kondisi fisik yang kuat untuk mencapai prestasi. Di dalam meningkatkan prestasi membutuhkan kelentukan dan kekuatan kondisi fisik.

Hasil dari prestasi olahraga renang ditentukan oleh jarak serta waktu tempuh 
secepat-cepatnya sehingga memperoleh hasil maksimal bagi performa. Komponen kecepatan gerak (spead movement) kuat sekali kaitannya dengan komponen kekuatan, kelincahan, keseimbangan, koordinasi dan daya tahan. Kecepatan gerak diukur dengan cara mengukur jarak yang ditempuh dan waktu yang dibutuhkan untuk menempuh jarak tersebut (meter / detik).Tipe pelatihan kondisi anaerobic renang gaya dada 100 meter ini diterapkan disini dengan beban intensitas yang tinggi, pada jarak 200 meter. Daya tahan adalah kemampuan tubuh dalam melakukan aktivitas terus-menerus yang berlangsung cukup lama, termasuk pengulangan pada repetisi dan set pada satu session $^{2}$. Dalam hal ini yang dimaksud gerakan kondisi anaerobic adalah renang secepat-cepatnya sebagai kemampuan untuk bergerak dari satu tempat ke tempat yang lain dalam waktu tempuh yang sesingkat mungkin. Sedangkan volume pelatihan yang menyangkut jumlah repetisi serta set penting dalam meningkatkan komponen biomotorik ${ }^{2}$. Pada komponen biomotorik yang dominan adalah kecepatan, daya tahan, kekuatan, kelentukan, dan koordinasi. Kemampuan untuk mempertahankan tubuh dalam air lazim juga disebut daya tahan.

Sedang volume latihan yang menyangkut repetisi dan set sangat penting juga dalam meningkatkan komponen biomotorik serta salah satu unsur yang termasuk dalam densitas adalah frekuensi ${ }^{2}$. Pelatihan olahraga renang secara umum dengan takaran suatu pelatihan mengandung tiga unsur pokok yaitu: intensitas, volume, dan densitas pelatihan. Takaran pelatihan awal yang diberikan dapat mengacu pada kemampuan sebenarnya dari atlet ${ }^{2}$.

\section{BAHAN DAN METODE}

Penelitian ini dengan menggunakan rancangan Exsperimental Randomized Pretest-Postes Control Grup Design 6 . Masing-masing kelompok terdiri dari 13 sampel semuanya laki-laki. Kelompok Perlakuan diberikan pelatihan $8 \times 25$ meter pengulangan, 4 repetisi, 5 set, istirahat satu repetisi 5 detik dan istirahat satu set 5 menit dan Kelompok Kontrol diberikan pelatihan 4 x 50 meter pengulangan, 3 repetisi, 5 set, istirahat satu set 5 menit selama 3 kali selama seminggu dengan kurun waktu 6 minggu. Penelitian ini dilaksanakan di SMK Negeri 2 Kota Kupang Nusa Tenggara Timur. Populasi target pada penelitian ini adalah siswa SMK di Kupang serta populasi terjangkau adalah siswa SMK Negeri 2 Kupang Nusa Tenggara Timur dengan jumlah 26 sampel.

Teknik pengambilan sampel calon sampel dikumpulkan sesuai dengan kriteria inklusi dan eksklusi.Melakukan pembagian kelompok menjadi dua bagian dengan cara undian yaitu angka ganjil pada Kelompok Perlakuan dan angka genap pada Kelompok Kontrol. Pelatihan renang diberikan pada Kelompok Perlakuan 8 kali 25 meter pengulangan, 4 repetisi, 5 set 3 kali seminggu selama 6 minggu dan pada pelatihan renang Kelompok Kontrol dengan 4 kali 50 meter pengulangan, 3 repetisi, 5 set, 3 kali satu minggu selama 6 minggu. Penelitiannya dengan prosedur: 1.Mencatat identitas diri sampel yang berhubungan dengan nama, umur, dan jenis kelamin. 2.Mengukur antropometrik yang menyangkut umur ( thn), tinggi badan $(\mathrm{cm})$ berat badan $(\mathrm{kg})$, dan indeks massa tubuh $\left(\mathrm{kg} / \mathrm{m}^{2}\right)$. 3.Mengukur waktu tempuh renang gaya dada 100 meter sehari sebelum pelatihan atau aktivitas.Sampel berjumlah 26 siswa diberikan beban pelatihan renang pada kondisi anaerobic Kelompok Perlakuan $8 \mathrm{x}$ 25 meter pengulangan, 4 repetisi, 5 set dengan kurun waktu 3 kali satu minggu selama 6 minggu yang terdapat pada tabel 1 .

Tabel 1. Pelatihan renang Kelompok Perlakuan $8 \times 25$ meter pengulangan, 4 repetisi, 5 set.

\begin{tabular}{llllllll}
\hline $\mathrm{R}$ & $\mathrm{R}$ & $\mathrm{R}$ & $\mathrm{R}$ & $\mathrm{R}$ & $\mathrm{R}$ & $\mathrm{R}$ & $\mathrm{R}$ \\
cepat & cepat & cepat & cepat & cepat & cepat & cepat & cepat \\
$\downarrow$ & $\uparrow$ & $\downarrow$ & $\uparrow$ & $\downarrow$ & $\uparrow$ & $\downarrow$ & $\uparrow$ \\
\hline
\end{tabular}


$\begin{array}{llllllll}25 \mathrm{~m} & 25 \mathrm{~m} & 25 \mathrm{~m} & 25 \mathrm{~m} & 25 \mathrm{~m} & 25 \mathrm{~m} & 25 \mathrm{~m} & 25 \mathrm{~m}\end{array}$

Keterangan : Panjang kolam renang yang dipergunakan 25 meter jadi setiap menempuh jarak 25 meter siswa akan kembali balik arah sampai delapan kali

Sedangkan pelatihan pada kondisi anaerobic Kelompok Kontrol 4 x 50 meter pengulangan, 3 repetisi, 5 set terdapat pada tabel 2 pelatihan sebanyak 3 kali satu minggu selama 6 minggu.

Tabel 2. Pelatihan renang Kelompok Kontrol 4 x 50 meter pengulangan, 3 repetisi, 5 set.

\begin{tabular}{llll}
\hline $\begin{array}{l}\text { R cepat } \\
\uparrow\end{array}$ & R cepat & R cepat & R cepat \\
$\uparrow$ & $\uparrow$ & $\uparrow$ \\
\hline $50 \mathrm{~m}$ & $50 \mathrm{~m}$ & $50 \mathrm{~m}$ & $50 \mathrm{~m}$ \\
\hline
\end{tabular}

Keterangan: Panjang kolam renang yang dipergunakan 25 meter sehingga setiap siswa menempuh jarak 25 meter harus kembali balik arah sampai delapan kali

\section{Analisis Data}

Sebelum melakukan uji statistik terlebih dahulu dilakukan uji normalitas data dan homogenitas data. Uji normalitas data menggunakan Shapiro Wilk Test p>0,05 maka data berdistribusi normal, kemudian dilakukan uji parametrik. Uji homogenitas data dengan menggunakan Levene's test didapatkan nilai signifikan $\mathrm{p}>0,05$ maka data tersebut bersifat homogen. Analisis data dengan paired t-test dan independent t-test. Batas kemaknaan ditetapkan 0,05

\section{HASIL PENELITIAN}

\section{Karakteristik Subjek Penelitian.}

Karakteristik subjek penelitian diuji homogenitas dapat dilihat pada tabel 3.Penelitian melibatkan 26 orang sampel dengan karakteristik umur, tinggi badan, berat badan, indeks masa tubuh.
Tabel 3. Karakteristik Subjek Penelitian dan Hasil Uji Homogenitas Data $(\mathrm{N}=26)$

\begin{tabular}{|c|c|c|c|c|}
\hline \multirow{3}{*}{ No. } & \multirow{3}{*}{ Variabel } & \multicolumn{2}{|r|}{ Kelompok } & \multirow[b]{3}{*}{ Levene test } \\
\hline & & \multirow[b]{2}{*}{$\begin{array}{l}\text { Perlakuan } \\
(\mathrm{N}=13)\end{array}$} & \multirow[b]{2}{*}{$\begin{array}{l}\text { Kontrol } \\
(\mathrm{N}=13)\end{array}$} & \\
\hline & & & & \\
\hline 1 & Umur (th) & $17,46 \pm 1,05$ & $16,85 \pm 1,21$ & 0,767 \\
\hline 2 & $\begin{array}{l}\text { Tinggi badan } \\
(\mathrm{cm})\end{array}$ & $162,92 \pm 1,26$ & $162,31 \pm 1,03$ & 0,300 \\
\hline 3 & $\begin{array}{l}\text { Berat badan } \\
(\mathrm{kg})\end{array}$ & $62,62 \pm 0,87$ & $61,92 \pm 1,19$ & 0,871 \\
\hline 4 & I MT ( kg/m²) & $19,22 \pm 0,32$ & $19,08 \pm 0,41$ & 0,375 \\
\hline
\end{tabular}

\section{Uji Normalitas Dan Homogenitas}

Dengan hasil uji normalitas (uji saphiro wilk) pada Kelompok Perlakuan dan Kelompok Kontrol sebelum dan sesudah pelatihan berdistribusi normal dapat di lihat pada tabel 4. Berdasarkan hasil uji homogenitas dan normalitas data, maka uji yang digunakan selanjutnya adalah uji statistik parametrik.

Tabel 4.Uji Normalitas Data

\begin{tabular}{lccc}
\hline Kelompok & N & P & Keterangan \\
\hline Perlakuan pretest & 13 & 0,129 & Normal \\
Kontrol pretest & 13 & 0,378 & Normal \\
Perlakuan posttest & 13 & 0,684 & Normal \\
Kontrol posttest & 13 & 0,774 & Normal \\
\hline
\end{tabular}

Keterangan : $\mathrm{N}=$ jumlah sampel, $\mathrm{p}=$ Signifikansi. Diuji Shapiro-Wilk. Hasilnya menunjukkan bahwa data berdistribusi normal $(\mathrm{p}>0,05)$.

$$
\text { Hasil uji homogenitas data }
$$
menggunakan uji levene's test pada 
Kelompok Perlakuan dan Kelompok Kontrol sebelum dan sesudah pelatihan data bersifat homogen dapat di liohat pada tabel 5.

Tabel 5 Uji Homogenitas Data

\begin{tabular}{lccc}
\hline $\begin{array}{l}\text { Kelompok } \\
\text { Data }\end{array}$ & $\mathrm{N}$ & $\mathrm{P}$ & Keterangan \\
\hline $\begin{array}{l}\text { Data } \\
\text { pretest }\end{array}$ & 26 & 0,807 & Homogen \\
$\begin{array}{l}\text { Data } \\
\text { posttest }\end{array}$ & 26 & 0,951 & Homogen \\
\hline
\end{tabular}

Diuji homogenitas dengan menggunakan Levene's test.Hasilnya menunjukkan bahwa varian data homogen $(p>0,05)$.

\section{Uji Deskriptif Data Hasil Penelitian}

Tabel 6.Data Deskriptif Variabel Penelitian.

\begin{tabular}{lccccc}
\hline Kelompok & $\begin{array}{c}\text { Rerata } \\
\text { Waktu } \\
\text { Tempuh } \\
\text { (detik) }\end{array}$ & SB & Median & Minimum & Maksimum \\
\hline $\begin{array}{l}\text { Perlakuan } \\
\text { pretest }\end{array}$ & 135,85 & 4,85 & 137,00 & 0,125 & 0,142 \\
$\begin{array}{l}\text { Kontrol } \\
\text { pretest }\end{array}$ & 134,77 & 4,23 & 135,00 & 0,127 & 0,140 \\
$\begin{array}{l}\text { Perlakuan } \\
\text { posttest }\end{array}$ & 114,23 & 5,22 & 115,00 & 0,103 & 0,122 \\
$\begin{array}{l}\text { Kontrol } \\
\text { posttest }\end{array}$ & 126,08 & 5,07 & 126,00 & 0,117 & 0,134 \\
\hline
\end{tabular}

Tabel 6. Data hasil penelitian pada Kelompok Perlakuan dan Kelompok Kontrol disajikan dalam Data bentuk deskriptif meliputi rerata, simpangan baku, median, minimum dan maksimum.

\section{Uji Efek Perlakuan pada Setiap Kelompok.}

Uji beda pelatihan renang anaerobic gaya dada 100 meter siswa antar Kelompok Perlakuan dan Kelompok Kontrol sebelum dan sesudah pelatihan dilakukan untuk mengetahui rerata perbedaan. Uji beda ini menggunakan paired sample t-test, dan uji statistik yang digunakan untuk membuktikan efek pelatihan Kelompok Perlakuan dan Kelompok Kontrol adalah independet t-test. Hasil uji pada tabel 7 dibawah ini.

Tabel 7. Hasil uji Efek Perlakuan Terhadap Kedua kelompok.

\begin{tabular}{|c|c|c|c|c|c|}
\hline \multirow{2}{*}{ Kelompok } & \multicolumn{2}{|c|}{ Waktu tempuh (detik) } & \multirow[t]{2}{*}{ Selisih } & \multirow{2}{*}{$\mathrm{t}$} & \multirow{2}{*}{$\mathrm{p}$} \\
\hline & Sebelum & Sesudah & & & \\
\hline Perlakuan & $135,85 \pm 4,85$ & $114,23 \pm 5,22$ & $21,62 \pm 3,53$ & 22,112 & 0,001 \\
\hline Kontrol & $134,77 \pm 4,23$ & $126,08 \pm 5,07$ & $8,69 \pm 1,55$ & 20,241 & 0,001 \\
\hline
\end{tabular}

Tabel 7. menunjukkan terjadi peningkatan waktu tempuh renang siswa pada Kelompok Perlakuan dengan pelatihan kondisi anaerobic $135,85 \pm 4,85$ detik menjadi $114,23 \pm 5,22$ detik ( $<<0,001)$. Selain itu, pada Kelompok Kontrol juga terjadi peningkatan waktu tempuh renang siswa dari $134,77 \pm 4,23$ detik menjadi 126,08 $\pm 5,07$ detik dengan hasil nilai $(p<0,001)$. Beda selisih setelah perlakuan antara Kelompok Perlakuan 21,62 $\pm 3,53$ detik dan Kelompok Kontrol menjadi 8,69 $\pm 1,55$ detik.

Hasil selisih peningkatan waktu tempuh renang siswa pada Kelompok Perlakuan lebih besar dibandingkan Kelompok Kontrol terlihat pada tabel 8 di bawah ini, yaitu Kelompok Perlakuan 21,62 $\pm 3,53$ detik dibandingkan Kelompok Kontrol 8,69 $\pm 1,55$ detik.

Tabel 8. Hasil Uji Komparasi Selisih Waktu Tempuh Ke dua Kelompok sesudah Perlakuan.

\begin{tabular}{llccc}
\hline $\begin{array}{l}\text { Kelompok } \\
\mathrm{N}\end{array}$ & Rerata $\pm \mathrm{SB}($ detik $)$ & ( Selisih) & $\mathrm{t}$ & $\mathrm{p}$ \\
\hline $\begin{array}{l}\text { Perlakuan } \\
13\end{array}$ & $21,62 \pm 3,53$ & & & \\
& & $15,15 \pm 7,109$ & 12,103 & 0,001 \\
$\begin{array}{l}\text { Kontrol } \\
13\end{array}$ & $8,69 \pm 1,55$ & & & \\
\hline
\end{tabular}

Dengan demikian selisih kecepatan waktu tempuh 95\% 15,15 $\pm 7,109$ Kelompok 
Perlakuan lebih baik dari pada Kelompok Kontrol renang gaya dada 100 meter.

\section{DISKUSI}

\section{Kondisi Subjek}

Karakteristik subjek penelitian yang meliputi: umur, tinggi badan, berat badan, Indeks masa tubuh pada 26 orang. Subjek yang digunakan dalam penelitian ini adalah siswa, jenis kelamin lelaki, berumur 15-19 tahun, dengan indeks masa tubuh (IMT) yang normal. Subjek penelitian dapat menunjukkan $\mathrm{p}>0,05$. Subjek tersebut dibagi menjadi dua yaitu Kelompok Perlakuan dan Kelompok Kontrol. Kelompok Perlakuan diberikan pelatihan $8 \quad$ x 25 meter pengulangan, 4 repetisi, 5 set selama 3 kali dalam seminggu selama 6 minggu dan Kelompok Kontrol 4 x 50 meter pengulangan, 3 repetisi, 5 set, selama 3 kali dalam seminggu selama 6 minggu.

Karakteristik dari Kelompok Perlakuan dan Kelompok Kontrol pada umur tidak berbeda bermakna dengan hasil uji homogenitas data menunjukkan $\mathrm{p}=0,767(\mathrm{p}>0,05)$. Dengan menunjukkan bahwa pada ke dua kelompok pelatihan memiliki karakteristik subjek penelitian dengan kondisi yang sama.

Subjek pelenelitian berdasarkan umur, Tinggi badan, berat badan, indeks masa tubuh (IMT) $\mathrm{kg} / \mathrm{m}^{2}$ keseluruhan dengan rincian pada Kelompok Perlakuan sebesar $19,22 \pm 0,32 \mathrm{~kg} / \mathrm{m}^{2}$ dan pada Kelompok Kontrol adalah 19,08 $\pm 0,41 \mathrm{~kg} / \mathrm{m}^{2}$ tidak berbeda bermakna. Hal ini menunjukkan kondisi sampel dari segi indeks massa tubuh masih normal. Indeks massa tubuh adalah cara termuda untuk memperkirakan atau mengindentifikasi tubuh yang mempunyai petunjuk berat badan dalam meter $\left(\mathrm{kg} / \mathrm{m}^{2}\right)^{7}$.

\section{Distribusi Normalitas dan Homogenitas Data Waktu Tempuh Kedua Kelompok}

Distribusi normalitas kecepatan waktu tempuh pada kedua kelompok sebelum dan sesudah pelatihan di lakukan dengan uji Shapiro- Wilk Test sedangkan varians antara kedua kelompok dengan Levenes Test. Variabel yang diamati pada penelitian ini adalah kecepatan waktu tempuh renang yaitu sebelum perlakuan dan sesudah perlakuan pada Kelompok Perlakuan dan pada Kelompok Kontrol. Data hasil penelitian disajikan dalam nilai $\mathrm{p}$ waktu tempuh awal Kelompok Perlakuan $\mathrm{p}=0,129$ dan kelompok kontrol $\mathrm{p}=0,378$.Sedangkan $\mathrm{p}$ untuk nilai sesudah perlakuan pada Kelompok Perlakuan $\mathrm{p}=0,684$ dan pada Kelompok Kontrol $\mathrm{p}=0,774$. Hasil uji normalitas untuk semua variabel di atas menunjukan $(p>0,05)$. Dengan ini berarti bahwa data dari ke dua kelompok perlakuan berdistribusi normal. Semua data tersebut di uji dengan parametric ${ }^{8}$. Hasil uji homogenitas data menunjukan bahwa pada kecepatan waktu tempuh sebelum perlakuan antara ke dua kelompok $\mathrm{p}=0,807$ dan sesudah perlakuan antara kedua kelompok $\mathrm{p}=0,951$. Variabel kecepatan waktu tempuh awal dan kecepatan waktu tempuh akhir penelitian menunjukan nilai $(p>0,05)$. Hal ini menunjukan data $\mathrm{p}$ tersebut adalah signifikansi. Data antara kelompok yang homogen di baca dari equa variances assumed.

\section{Efek Pelatihan Terhadap Waktu Tempuh.}

Hasil analisis kemaknaan diuji dengan Independent sample T-Test karena data berdistribusi normal, disajikan menunjukkan rerata kecepatan waktu tempuh siswa Kelompok Perlakuan sebelum diberikan perlakuan renang 100 meter dengan nilai $\mathrm{p}=0,552$. Hal ini berarti kedua kelompok sebelum diberikan perlakuan (pre-test) memiliki rerata kecepatan waktu tempuh siswa renang tidak berbeda bermakna nilai $\mathrm{p}=0,552(\mathrm{p}>0,05)$. Dengan demikian waktu tempuh renang gaya dada 100 meter sebelum pelatihan Kelompok Perlakuan dan Kelompok Kontrol adalah tidak berbeda bermakna, apabila terjadi peningkatan waktu tempuh setelah penerapan pelatihan.

Sesudah pelatihan selama 6 minggu pada kedua kelompok diuji dengan 
independent sample t-Test menunjukan antara Kelompok Perlakuan dan Kelompok Kontrol dengan hasil rerata waktu tempuh seletah perlakuan $\mathrm{p}=0,001(\mathrm{p}<0,05)$. Hal ini menunjukan bahwa setelah di berikan pelatihan selama 6 minggu terdapat hasil waktu tempuh renang yang berbeda bermakna $p<0,05$. Dengan demikian berarti bahwa rerata waktu tempuh renang gaya dada 100 meter sebelum dan sesudah pelatihan menunjukan berbeda bermakna. Dari hasil ini dapat dikatakan bahwa pelatihan pada Kelompok Perlakuan 8 x 25 meter pengulangan, empat repetisi, lima set dan Kelompok Kontrol 4 x 50 meter pengulangan, tiga repetisi, lima set yang diterapkan memiliki pengaruh dalam meningkatkan waktu tempuh renang pada kondisi anaerobic renang gaya dada 100 meter. Memberikan volume dan intensitas latihan pada Kelompok Perlakuan dan Kelompok Kontrol sebanyak mungkin terlihat di Tabel $5 \mathrm{p}<0,05$ menunjukan pada kedua kelompok yang bisa dilakukan pada pelatihan terdapat perbedaan yang bermakna. Pengulangan intensitas dan volume "Waktu yang lebih cepat yang dicatat untuk renang merupakan tanda dari kemajuan". Pelatih Mann. Robert Kiphuth dan lain-lain menyempurnakan metode-metode latihannya dengan lebih banyak memberikan tekanan terhadap kecepatan dalam bentuk Wind Sprints, seperti sepuluh sampai lima belas kali 50 m sprints pada akhir latihan ${ }^{9}$.

Hasil peningkatan waktu tempuh antara Kelompok Perlakuan dan Kelompok Kontrol terdapat perbedaan yang bermakna menunjukan $p=0,001(p<0,001)$. Dengan demikian hasil uji efek perlakuan pada Kelompok Perlakuan dan Kelompok Kontrol sebelum dan sesudah terbukti yaitu pelatihan pada kondisi anaerobic terhadap Kelompok Perlakuan 8 × 25 meter pengulangan, empat repetisi, lima set dan Kelompok Kontrol pelatihan 4 × 50 meter pengulangan, tiga repetisi dan lima set, dapat meningkatkan waktu tempuh renang gaya dada 100 meter.

Pengunaan berdasarkan repetisi pelatihan Kelompok Perlakuan lebih banyak dari pada Kelompok Kontrol. Pelatihan yang mengunakan repetisi yang lebih banyak dengan jumlah set dan total jarak sama tentu akan menghasilkan kecepatan waktu tempuh lebih besar dari pada pelatihan menggunakan repetisi lebih sedikit dengan jumlah set yang sama. Berdasarkan hasil kecepatan waktu tempuh siswa sebelum dan setelah perlakuan masing-masing kelompok terdapat nilai $\mathrm{p}<0,05$. Hal ini menunjukkan bahwa pelatihan gerakan siswa Kelompok Perlakuan lebih baik dari pada pelatihan Kelompok Kontrol. Berdasarkan perbedaan rerata waktu tempuh $\mathrm{p}<0,05$ terhadap kedua kelompok renang gaya dada 100 meter tersebut, maka perbedaan rerata pada kedua kelompok selama pelatihan yang dilakukan dari minggu pertama hingga minggu ke enam menunjukkan bermakna $\mathrm{p}=0,001(\mathrm{p}<0,05)$.

Selisih hasil waktu tempuh Kelompok Perlakuan pada pelatihan $8 \quad$ x 25 pengulangan, empat repetisi, lima set renang gaya dada 100 meter lebih baik dari pada Kelompok Kontrol dengan pelatihan 4 x 50 meter pengulangan, tiga repetisi, lima set, renang gaya dada 100 meter $\mathrm{p}=0,001$. Dengan demikian hasil selisih perbedaan Kelompok Perlakuan dan Kelompok Kontrol dapat diterima atau terbukti bahwa Kelompok Perlakuan hasilnya lebih besar dari Kelompok Kontrol dengan nilai $\mathrm{p}<0,001$. Beberapa faktor yang menunjang peningkatan waktu tempuh yaitu terdapat perbedaan pengulangan repetisi, set, pemulihan, sistim energy anaerobic yang digunakan ${ }^{10}$. Hal ini menyebabkan Kelompok Perlakuan sudah terlatih berenang dengan kecepatan waktu tempuh yang tinggi dari pada Kelompok Kontrol p<0,001. Perbedaan kecepatan waktu tempuh ini dapat menyebabkan Kelompok Perlakuan menghasilkan kecepatan waktu tempuh lebih baik dari pada Kelompok Kontrol selama pelatihan 6 minggu. Dalam melakukan latihan anaerobik, perlu beristirahat antara dua sesi latihan supaya tubuh memiliki cukup waktu untuk memulihkan dan membangun asam jika hal ini tidak 
dilakukan, tubuh atlet akan mengalami lebih banyak kerugian ${ }^{11}$.

Berdasarkan repetisi dan set tinggi tingkat pemakaian energy pada Kelompok Perlakuan perlakuan lebih tinggi dari Kelompok Kontrol, namun selama pemakaian energy yang tinggi tidak menyebabkan kelelahan yang berarti pada kedua kelompok sebab sudah tebiasa melakukan renang dengan penggunaaan repetisi yang maksimal. Periode puli asal akan terjadi suatu penurunan kadar laktat yang sangat cepat hal ini akan menyebabkan pelatihan lebih ringan,di sebabkan asupan energy dari glikolisis anaerobic atau sistim asam lactat akan menurun dan asupan energi dari posfagen ATP-PC. Pada olahraga yang sangat berat dengan waktu yang pendek, seperti sprint sistem energi yang dipakai adalah ATP-PC(adenosin tri phosphatephosphocreatine), dan asam laktat ${ }^{12}$.

Besarnya pemakaian energy di atas menunjukan perbandingan pemakaian energy phospgen Kelompok Perlakuan lebih besar dari pada Kelompok Kontrol. Penyediaan energy dari system phospagen berlangsung sangan cepat yaitu dua kali lipat dari kecepatan system asam laktat ${ }^{13}$. Metode ini menekankan pada kerja dengan intensitas yang sangat tinggi kemudian dilakukan dengan istirahat sempurna dengan waktu yang lebih panjang sehingga dalam melakukan latihan berikutnya siswa dapat melakukan lebih maksimal. Metode repetisi merupakan metode yang dapat meningkatkan kecepatan renang gaya bebas 50 meter karena metode latihan ini dengan pengulangan repetisi ${ }^{14}$. Perbandingan waktu tempuh antara Kelompok Perlakuan dan Kelompok Kontrol $p=0,001(p<0,001)$. Menunjukan jenis pelatihan renang ini dilakukan secara berulang kali dengan kecepatan tinggi atau dengan secepatcepatnya memberikan suatu perubahan pada Kelompok Perlakuan lebih baik dari pada Kelompok Kontrol renang gaya dada 100 meter, yang meliputi peningkatan subsrtak pada anaerobic seperti ATP, PC, kreatin dan glikogen yang lebih besar. Pada Tabel 5 menunjukan perbedaan rerata Kelompok Perlakuan 21,62 $\pm 3,53$ detik dan Kelompok Kontrol 8,69 $\pm 1,55$ detik sehingga menunjukan $p<0,001$. Disamping itu terjadi peningkatan jumlah dan aktivitas enzim yang berpengaruh terhadap peningkatan kecepatan renang ${ }^{15}$.

Volume pelatihan dengan set yang tinggi ini pada kedua kelompok baik Kelompok Perlakuan dan Kelompok Kontrol menghasilkan nilai $\mathrm{p}<0,001$ melibatkan sistim energi anatara lain ATP/PC yang sangat dominan, kemudian diikuti oleh penggunaan O2. Melatih 'Energy System' Tertentu (Spesifik) dengan pendekatan pada latihan kebanyakan nomor pertandingan memakan waktu hanya sekitar 2 menit ( kecuali $400 \mathrm{~m}$ ke atas) dan ini menandakan kalau system energy yang dominan adalah anaerobic. Kecepatan maksimal hanya bisa dipertahankan singkat saja, pasti terjadi penurunan setelah itu karena proses biokimia dan fisiologi dalam tubuh, seperti penurunan kadar ATP maupun Creatine Phosphate dalam otot, cara paling efektif membentuk speed adalah melalui latihan interval dengan kecepatan tinggi mendekati ambang maksimal $^{9}$.

Pelatihan beban pengulangan repetisi pada Kelompok Perlakuan 8 x 25 meter pengulangan, empat repetisi, lima set dan Kelompok Kontrol 4 x 50 meter pengulangan, tiga repetisi, lima set dalam pelatihannya sangat membutuhkan waktu tempuh singkat dengan energy yang tinggi. Sehingga model pelatihan melibatkan banyak otot yang bekerja yang maksimal dan tenaga yang tinggi atau lebih besar. Apabila otot terlatih lebih banyak, persediaan ATP menjadi lebih besar ${ }^{17}$. Kecepatan maksimal hanya bisa ditingkatkan bila perenang berlatih dengan kecepatan mendekati atau sama dengan kecepatan waktu lomba. Bisa juga dengan latihan melebihi kecepatan lomba dengan 'speed assisted drill' menggunakan fins atau paddles ${ }^{9}$. 


\section{SIMPULAN}

Pelatihan renang gaya dada 100 meter pada kondisi anaerobic secepat-cepatnya Kelompok Perlakuan 8 kali 25 meter pengulangan, empat repetisi, lima set dan Kelompok Kontrol 4 kali 50 meter pengulangan, tiga repetisi, lima set, dapat meningkatkan waktu tempuh renang siswa SMK Negeri Kupang Nusa Tenggara Timur

\section{DAFTAR PUSTAKA}

1. Riduwan, 2010.Skala Pengukuran Variabel-veriabel Penelitian. Bandung : Alfabeta

2. Nala, N., 2015. Prinsip Pelatihan Fisik Olahraga. Denpasar: Komite Nasional Indonesia Daerah Bali

6. Pocock, S. J., 2008. Clinical Trial, A Practical Approach. New York: John Wiley and Sons.

7. Pudjiadi,AH., 2010, Pedoman Pelayanan Medis Ikatan Dokter Anak Indonesia,Pengurus Pusat Ikatan Dokter Anak Indonesia (IDAI), Jakarta.

8. Dahlan, Sopiyudin., 2011.Statistik Untuk Kedokteran dan Kesehatan Edisi 5. Jakarta, Salemba Medika

9. Supriyanto, A., 2013. Pedoman Identifikasi Pemanduan Bakat Istimewa http://swimming-fastestid.blogspot.com/2013/07/membentukspeed-pada-perenang-tamat.html.Di daunload 15/03/2019.PDF
10. Bompa, T.O., Harf, G.G., 2009. Periodezation Training For Sport: Programs For Peak Streght In 35 Sports United State Of America. Human Kinestics

11. Nurkadi, 2013. Pengabdian Kepada Masyarakat Vol. 19 Nomor 73 Tahun XIXSeptember,(2013:106),https://jurnal.un imed.ac.id/2012/index.php/jpkm/article/v iew/4748/4176 Daundload tanggal $17 / 03 / 2019$

12. Adnyana, G., 2011. Model Konstruktivistik Dalam Pembelajaran. online. Tersedia : http://www.psb psma.org/content/blog/4009modelkonstr uktivistik-dalam-pembelajaran Diakses tanggal 25 April 2019.

14. Surahman, F., 2016. Pelatihan Renang dengan Anaeobic http://doi.org/10.22216/jcc.2016.v1i2.21 6http://ejournal.kopertis10.or.id/index.ph p/curricula/article/download/216/234. Di daunload tanggal 17/03/2019. PDF.

15. McArdle, W.D., Katch, F.I., Katch,V.I., 2001. Exsercise Physiology Energy, Nutrition, and Humen Performance. Philadelpia: Lea and Febiger

17. Guyton, Hall, 2007. Buku Ajar Fisiologi Kedokteran. Jakarta: Penerbit Buku Kedokteran EGC. 
